\title{
Cacti-associated rhizobacteria from Brazilian Caatinga biome induce maize growth promotion and alleviate abiotic stress
}

\author{
Adailson Feitoza Jesus Santos ${ }^{1} \oplus$, Jildemar Santos de Morais ${ }^{1} \mathbb{\infty}$, Jean Santana Miranda ${ }^{1}$, \\ Zayda Piedad Morales Moreira ${ }^{2} \odot$, Adriane Freire Araújo Feitoza ${ }^{3} \odot$, Jakson Leite ${ }^{4}$, Paulo Ivan Fernandes-Júnior ${ }^{5}$

\footnotetext{
1 Universidade do Estado da Bahia, Juazeiro, BA, Brasil. E-mail: adailsonmicrobiologia@gmail.com; gilsantos42@hotmail.com; jean.s.m@hotmail.com

${ }^{3}$ Universidade Federal do Recôncavo da Bahia, Cruz das Almas, BA, Brasil. E-mail: adrianebiologa@yahoo.com.br

${ }^{4}$ Universidade Federal do Maranhão, Bacabal, MA, Brasil. E-mail: leitejk@gmail.com

${ }^{5}$ Embrapa Semiárido, Petrolina, PE, Brasil. E-mail: paulo.ivan@embrapa.br
} \\ 2 University of Saskatchewan, College of Agriculture and Bioresources, Saskatoon, SK, Canada. E-mail: zpm118@usask.ca
}

\begin{abstract}
The aim of this study was to isolate and characterize the culturable rhizobacteria associated with native cacti from Caatinga biome, testing their potential in plant growth promotion and abiotic stress tolerance. Bacterial isolates were examined for plant growth promotion traits and for in vitro abiotic stress tolerance. Promising isolates were 16S rRNA sequenced, tested under greenhouse conditions for plant growth promotion and induction of water deficit tolerance in maize plants. Analysis of variance was used to assess differences among treatments and, when significant, followed by the Scott-Knott's test. The highest culturable population density was found in Melocactus zehntneri and the most promissing isolates belonged to the genus Bacillus. Under recommended conditions of irrigation, plants inoculated with the isolates CF12.2, CF8.2, and P12.2 presented an increment in root length, leaf number and root and shoot dry weight. Additionally, isolates CF6.1, CF3.1, CF8.2 and P12.2, increased shoot dry weight under water deficit conditions. In this study we identified bacterial taxa for further validation and application as biostimulants in crops grown in drylands.
\end{abstract}

Key words: Bacillus; PGPR; semi-arid; water deficit

\section{Rizobactérias associadas a cactáceas do bioma Caatinga induzem promoção de crescimento e reduzem o estresse abiótico em milho}

RESUMO: O objetivo deste estudo foi isolar e caracterizar rizobactérias cultiváveis associadas com cactáceas nativas do bioma Caatinga, testando seu potencial na promoção de crescimento de milho e na tolerância a seca. Isolados bacterianos foram testados para promoção de crescimento vegetal e tolerância a estresse abiótico. Nos isolados promissores a região 16S rRNA foi sequenciada e foram testados em condições de casa de vegetação para promoção de crescimento vegetal e indução de tolerância a déficit hídrico em plantas de milho. A análise de variância foi utilizada e médias comparadas pelo teste de ScottKnott. A maior densidade populacional cultivável foi encontrada em Melocactus zehntnerie os isolados mais promissores foram identificados como pertencentes ao gênero Bacillus. Em condições de irrigação, as plantas inoculadas com os isolados CF12.2, CF8.2, e P12.2 mostraram incremento no comprimento da raiz, número de folhas e massa seca da raiz e parte área. Além disso, os isolados CF6.1, CF3.1, CF8.2 e P12.2, aumentaram a massa seca da parte aérea em condições de déficit hídrico. Foram identificadas bactérias que podem futuramente ser validades e aplicadas como bioestimulantes em culturas de interesse agrícola em áreas secas.

Palavras-chave: Bacillus; PGPR; semiárido; déficit hídrico 


\section{Introduction}

The Caatinga biome is characterized by a large variety of vegetation with a high number of species, including a significant number of endemic taxa (Giulietti et al., 2003). In 2002, 18 genera and 318 endemic species belonging to 42 families were listed in the Biome.

The Cactaceae family is worldwide recognized due to its several uses (Lucena et al., 2013) and includes around 1400 succulent an non-succulent species distributed throughout the American continent (Guerrero et al., 2019). The wide distribution of this family in Brazil is represented by 39 genera, of which 14 are endemic, including 261 species, (BFG, 2015). Cereus jamacaru, Tacinga inamoena, T. werneri, T. palmadora, Pilosocereus gounellei subsp. gounellei, P. catingicola subsp. salvadorensis, Pseudoacanthocereus brasiliensis, Melocactus zehntneri, Arrojadoa penicillata, Coleocephalocereus aureus, Micranthocereus dolichospermaticus, M. streckeri, Stephanocereus luetzelburgii, Arrojadoa bahiensis, are some of the native species of cacti in Brazil. In the Caatinga biome, 63 endemic species are recorded (Silva et al., 2011).

Like other plant species, cacti have associations with microorganisms, mainly fungi and bacteria, in all compartments (Kavamura et al., 2013b; Fonseca-García et al., 2016). Information regarding the importance of the association, as well as the factors influencing this relationship with the host remains unknown. Previous reports have shown the contribution of bacterial communities in plants belonging to this family. When three cactus species were inoculated with Azospirillum brasilense, higher survival rates as well as higher growth rates were observed in eroded soils (Bashan et al., 1999). Similarly, endophytes found in Pachycereus pringlei seeds were crucial for seedlings development under extreme conditions (Puente et al., 2009).
Recent studies have shown that microorganisms can affect plant physiology since they produce compounds such as phytohormones and siderophores (Pahari et al., 2017; Maharana, 2019). Furthermore, microbes act as phosphate solubilizers, $\mathrm{N}_{2}$-fixers and are antagonists against fungal pathogens (Ryan et al., 2009; Kim et al., 2012; Ogbo \& Okonkwo, 2012; Dalal \& Kulkarni, 2013). All these characteristics are involved directly or indirectly in plant growth promotion.

Moreover, there are studies showing the association of these microorganisms and the abiotic stress resistance exhibited by the host, including high salt concentration, high temperatures and water deficit (Mutumba et al., 2018; Albdaiwi et al., 2019; Ashraf et al., 2019, Santana et al. 2020). These factors are characteristic of arid and/or semi-arid regions and may lead to the reduction and/or loss of agricultural production. Consequently, the use of microorganisms could assure a sustainable and ecological practice.

The aim of this study was to isolate and characterize the culturable rhizobacteria associated with native cacti from the Caatinga biome, testing their potential in maize growth promotion and drought stress tolerance.

\section{Materials and Methods}

\section{Quantification and isolation of cacti rhizospheric bacteria}

Two sites were selected within the area of the Ecological Station - ESEC/Raso da Catarina, which exhibits diverse vegetation and have no impact of human activities. Rhizospheric soil samples were collected from three cacti species (Pilosocereus catingicola subsp. salvadorensis, Tacinga werneri and Melocactus zehntneri) (Figure 1). Roots were sampled at $20 \mathrm{~cm}$ depth and the soil adhered to the root system was used. Compound samples were prepared with five subsamples of each species at each collection site

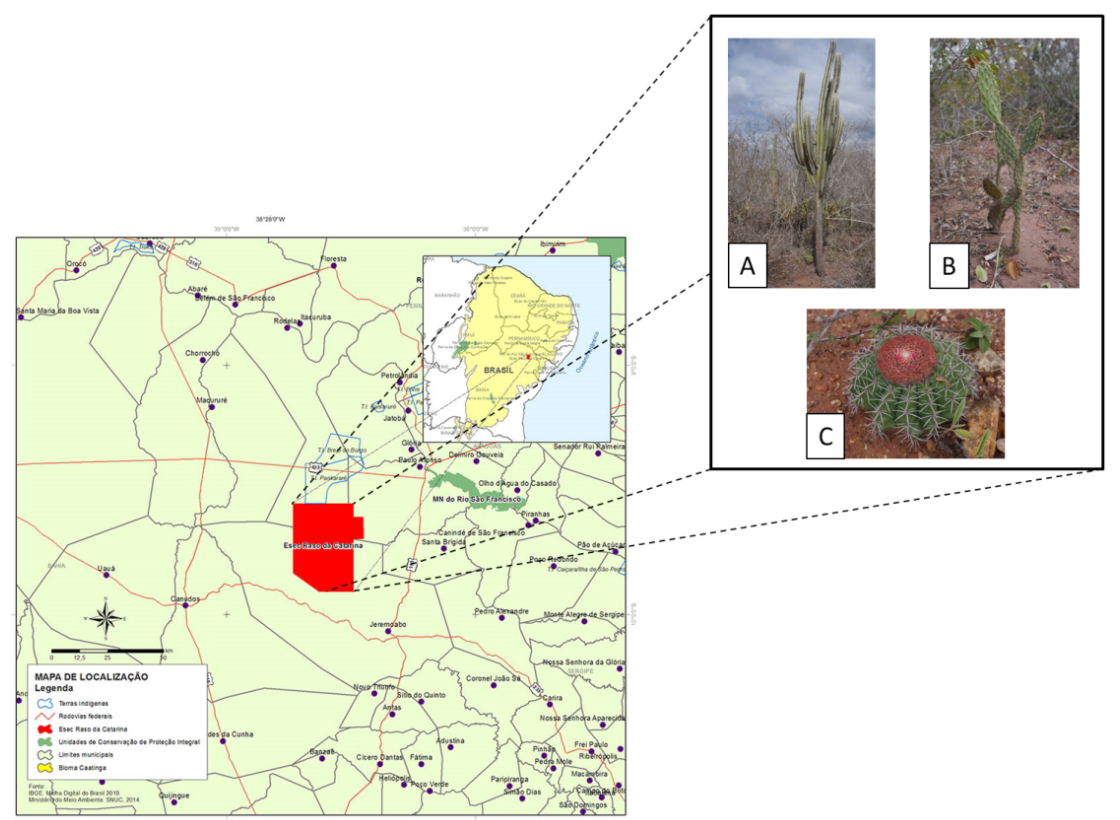

Figure 1. 'Raso da Catarina' Ecological Station location (shown in red on the map). Cacti species used in this study: (A) Pilosocereus catingicola subsp. salvadorensis, (B) Tacinga werneri and (C) Melocactus zehntneri 
and immediately transported to the Laboratory in styrofoam boxes.

Ten grams of each soil sample was transferred to an Erlenmeyer containing $90 \mathrm{~mL}$ of saline solution ( $\mathrm{NaCl} 0.85 \%$ ) for rhizobacteria quantification and isolation. Rhizospheric bacteria were isolated by serial dilution and plated on Tryptone Soya Agar - TSA (10\%). Plates were incubated at $28 \pm 2{ }^{\circ} \mathrm{C}$ for $48 \mathrm{~h}$. Ten morphologically distinct colonies were selected from each sample and transfer to new TSA plates for further purification. All isolates were characterized by Gram staining.

\section{Screening of plant growth-promoting traits}

Inorganic phosphate solubilization - A first solution containing $0.57 \mathrm{~mol} \mathrm{~L}^{-1} \mathrm{~K}_{2} \mathrm{HPO}_{4}$ and a second containing 0.90 $\mathrm{mol} \mathrm{L}^{-1} \mathrm{CaCl}_{2}$, were added to a GL medium ( $\mathrm{g} \mathrm{L}^{-1}: 10.0$ glucose, 2.0 yeast extract and 15.0 Agar) to induce the formation of calcium phosphate precipitates. Five microliters of bacterial suspension with an optical density (OD $600 \mathrm{~nm}$ - 0.2) from each isolate were placed on plates containing the culture medium. Plates were incubated at $28 \pm 2{ }^{\circ} \mathrm{C}$ for 10 days. The formation of a clear halo around the colonies was considered as positive for phosphate solubilization, as described by Santos et al. (2014).

Asymbiotic nitrogen fixation - Each isolate was transferred to test tubes containing $5 \mathrm{~mL}$ of Burk's semi-solid nitrogenfree medium (g L-1: 10.0 glucose, $0.41 \mathrm{KH}_{2} \mathrm{PO}_{4^{\prime}} 0.52 \mathrm{~K}_{2} \mathrm{HPO}_{4^{\prime}}$ $0.05 \mathrm{Na}_{2} \mathrm{SO}_{4}, 0.2 \mathrm{CaCl}_{2}, 0.1 \mathrm{MgSO}_{4} 7 \mathrm{H}_{2} \mathrm{O}, 0.0025 \mathrm{Na}_{2} \mathrm{MoO}_{4} .2$ $\mathrm{H}_{2} \mathrm{O}, 0.005 \mathrm{FeSO}_{4} .7 \mathrm{H}_{2} \mathrm{O}$ and 1.8 agar, $\mathrm{pH}$ 7.0) (Wilson \& Knight, 1952). The tubes were incubated at $28 \pm 2{ }^{\circ} \mathrm{C}$ for 7 days. The formation of a characteristic growth film was considered as positive for nitrogen-fixing bacteria.

Siderophores production - Three solutions were prepared. Solution 1: $0.06 \mathrm{~g}$ of Chromo Azurol S (CAS) dissolved in $50 \mathrm{~mL}$ of distilled water. Solution 2: $0.02 \mathrm{~g} \mathrm{FeCl}_{3}$ and 83.3 $\mu \mathrm{L}$ of $\mathrm{HCl}$ in $100 \mathrm{~mL}$ of distilled water. Solution 3: $0.072 \mathrm{~g}$ of hexadecyltrimethylammonium bromide (HDTMA) was dissolved in $40 \mathrm{~mL}$ of distilled water. Solution 1 was mixed with 2 and then with 3 . The solution was autoclaved and for each $900 \mathrm{~mL}$ of TSA medium, $100 \mathrm{~mL}$ of the solution was added. The isolates were transferred to the plates and a yellow-orange halo formation indicated siderophores production (Louden et al., 2011). Strains of Staphylococcus aureus and Escherichia coli were used as negative and positive controls, respectively.

Indole compounds - The colorimetric method described by Gordon \& Weber (1951) was followed using $10 \mu$ of bacterial suspension (OD $600 \mathrm{~nm}-0.2-10^{9}$ cells $\mathrm{mL}^{-1}$ ).

Exopolysaccharides (EPS) production - Using the methodology described by Paulo et al., (2012), the EPS production was evaluated in a modified medium by Guimarães et al. (1999), containing $2 \%$ of yeast extract, $1.5 \% \mathrm{~K}_{2} \mathrm{HPO}_{4^{\prime}}$ $0.02 \% \mathrm{MgSO}_{4}, 0.0015 \% \mathrm{MnSO}_{4}, 0.0015 \% \mathrm{FeSO}_{4}, 0.003 \% \mathrm{CaCl}_{2}$, 1.5\% Agar and $10 \%$ sucrose, with the $\mathrm{pH}$ adjusted to 7.5 .

In vitro root colonization - The assay was performed following the methodology described by Queiroz et al. (2006). Surface disinfested maize seeds (70\% alcohol, $1 \%$ sodium hypochlorite and three consecutive washes in sterile distilled water) were transferred to test tubes containing $0.8 \%$ water agar medium. After germination, the seeds were inoculated with bacterial suspension (OD600 $\mathrm{nm}=0.2$ ) and incubated for 5 days at room temperature. Each treatment consisted of 5 replicates and the formation of a white film around the root system was used as a parameter to determine colonization.

\section{Screening for abiotic stress tolerance traits}

Salinity tolerance - The isolates were streaked in TSA media (10\%) supplemented with different $\mathrm{NaCl}$ concentrations $(0,2$, $4,6,8$ and $10 \%$ ). Plates were incubated at $28 \pm 2{ }^{\circ} \mathrm{C}$ for $48 \mathrm{~h}$.

Water deficit tolerance-Bacterial colonies were transferred to Petri dishes containing TSA medium (10\%) supplemented with sorbitol at different concentrations $(285,405,520$ and $780 \mathrm{~g} \mathrm{~L}^{-1}$ ) corresponding respectively to $0.963,0.930,0.912$ and 0.837 of water activity (WA) (Hallsworth et al., 1998). The isolates were incubated at $28 \pm 2{ }^{\circ} \mathrm{C}$ for $48 \mathrm{~h}$.

Tolerance at high temperatures - The isolates were streaked in TSA medium (10\%) and incubated for $48 \mathrm{~h}$ at different temperatures, $28{ }^{\circ} \mathrm{C}$ was used as a control. The evaluated temperatures were: $37,42,45$ and $49{ }^{\circ} \mathrm{C}$. Bacterial growth was evaluated after the incubation period.

\section{S rRNA amplification and sequencing}

DNA was extracted from pure cultures grown during $24 \mathrm{~h}$ on broth media over an orbital shaker at $180 \mathrm{rpm}$ at room temperature. DNA extraction was carried out using the HiYield $^{\mathrm{TM}}$ Genomic DNA Mini Kit (Real Biotech Corporation, Taipei, Taiwan) following the manufacturer's instructions.

16S rRNA gene was amplified from DNA samples by PCR using 27F (5'-AGAGTTTGATCMTGGCTCAG-3') and 1492R (5'-TACGGYTACCTTGTTACGACTT-3') primers (with expected amplicon size of $1465 \mathrm{bp}$ ). Each PCR reaction was carried out following the Weisburg et al. (1991) methodology. PCR products were sequenced by Macrogen (Seoul, South Korea) using a $3730 \mathrm{xl}$ sequencer (Applied Biosystems, Drive Foster City, CA, USA). Sequences were analyzed using the Sequence Scanner Software v. 2.0 (Applied Biosystems) and the contigs assembled using the BioEdit software $v 7.0$ (http://mbio. ncsu.edu/BioEdit/bioedit.html). Sequences were deposited in GenBank, a database of the National Center for Biotechnology Information (www.ncbi.nlm.nih.gov/Genbank) under the accession numbers MF574389 to MF574393.

The 16S rRNA sequences were identified by comparison with those deposited in EzBioCloud database (Yoon et al., 2017). Phylogenetic analysis was performed using MEGA 6.0 software (Tamura et al., 2013). Multiple sequence alignments were performed using ClustalW through MEGA 5.0, and a neighbor-joining phylogenetic reconstruction was performed using the Kimura two-parameter substitution model for calculation of the distance matrices using 1000 pseudoreplicates. The software default parameters were considered for all analyses.

Plant growth promotion under water stressed and water non-stressed conditions

Maize seeds, variety "Catete", were sowed in pots containing $4 \mathrm{~kg}$ of soil, in each pot, in each pot 5 seeds were 
sowed and after the emergence, two plants per pot were kept. Two independent experiments were set up in order to test the ability of 5 bacteria to induce maize growth and water deficit tolerance. In the first experiment, the field capacity of $80 \%$ was used, while in the second experiment the field capacity was reduced to $30 \%$.

Isolates were streaked into Petri dishes containing TSA medium and incubated at $28 \pm 2{ }^{\circ} \mathrm{C}$ for $48 \mathrm{~h}$. The inoculum was prepared from the adjusted bacterial suspension (OD 600 $\mathrm{nm}-0.2=10^{9}$ cells $\mathrm{mL}^{-1}$ ). For both assays, the inoculation was performed directly on the soil near to the base of the plants, using $10 \mathrm{~mL}$ of the selected isolates (CF12.2, CF6.1, CF3.1, CF8.2 and P12.2) and reinoculated after 20 days following the same methodology. The control was set as $10 \mathrm{~mL}$ of $\mathrm{NaCl}$ $0.85 \%$. The irrigation conditions were the same during 20 days for both experiments ( $80 \%$ of field capacity). From day $21^{\text {st }}$ the soil moisture was maintained with normal irrigation in the first trial and in the second trial, the amount of water was reduced in order to simulate drought conditions $(30 \%$ of field capacity). Plants were kept under greenhouse conditions for 45 days. The experiment was set up in a greenhouse in a randomized block design with thirteen replications. Root and shoot dry weight, length and number of leaves were determined. Analysis of variance (ANOVA) was performed to test differences among treatments and, when significant, followed by post hoc Scott-Knott test $(p<0.05)$. The Sisvar 5.0 software package (Ferreira, 2011) was used.

\section{Results and Discussion}

\section{Rhizobacteria isolation}

Ninety bacterial strains with morphological differences were isolated. Of these, $88 \%$ were classified as Gram positive and $12 \%$ as Gram negative. The quantification of the rhizospheric bacteria ranged from $2.4 \times 10^{4}$ to $1.4 \times 10^{6} \mathrm{CFU}$ $\mathrm{g}^{-1}$, where the largest culturable population was associated with Melocactus zehntneri species (Table 1). Samples from site 2 showed higher population densities in all plant species explored. There are few studies analyzing the microbial community associated with cacti roots in the Brazilian semiarid region. Recent publications described the ability of these isolates to promote plant growth (Kavamura et al., 2013a). The quantifications of the culturable isolates in our study are lower than those described in other three cacti species cultivated in Mexico - 5,6×10 CFU (g dry soil-1) (Aguirre-Garrido et al., 2012). The dynamics of the microbial community inhabiting the rhizosphere is influenced by abiotic factors, including dry and rainy periods, in which communities are predominant during the rainy season (Aguirre-Garrido et al., 2012). Biotic factors such as plant development stage (Chaparro et al., 2014) and host genotype (Berg \& Smalla, 2009) also influence microbial communities. Root exudates could explain variations in microbial communities among plant species and cultivars of the same species (Micallef et al., 2009). Our study showed that the density of the rhizobacteria community was influenced both by plant species and collection site.
Table 1. Quantification of culturable rhizobacteria associated to different species of cacti in two studied sites at ESEC - 'Raso da Catarina'.

\begin{tabular}{lll}
\hline \multicolumn{1}{c}{ Cacti species } & $\begin{array}{c}\text { Site 1 } \\
\text { CFU g }\end{array}$ & $\begin{array}{c}\text { Site 2 } \\
\text { CFU g-1 }\end{array}$ \\
\hline Melocactus zehntneri & $1.9 \times 10^{5}$ & $1.4 \times 10^{6}$ \\
Tacinga werneri & $6.4 \times 10^{4}$ & $9.0 \times 10^{5}$ \\
Pilosocereus catingicola & $2.4 \times 10^{4}$ & $5.8 \times 10^{5}$ \\
\hline
\end{tabular}

In vitro plant growth-promoting traits and bacterial growth under abiotic stress

All isolates were positive for at least one of the five plant growth promotion traits evaluated in vitro. For the solubilization of inorganic phosphate, $6 \%$ of the isolates were positive, $27 \%$ produced siderophores, $37 \%$ fixed nitrogen, $61 \%$ produced indolic compounds and 59\% produced EPS (Table 2). The distribution of the abiotic stress tolerant isolates between the different cacti species and the distribution by sampling sites are detailed in Table 2. Clearly, there is a reduction in the growth of the isolates under extreme environmental conditions, such as high salinity, low water availability and high temperatures. However, it is important to highlight that $12 \%$ of the isolates grew under the highest salt concentration, $14 \%$ tolerated low water activity $\left(w_{A} 0.807\right)$ and $11 \%$ were able to grow at $49{ }^{\circ} \mathrm{C}$.

Table 2 shows that isolates from site 2, regardless the analyzed species, exhibited higher tolerance to $\mathrm{NaCl}$ and temperature. Furthermore, isolates that grew at $49{ }^{\circ} \mathrm{C}$ and high $\mathrm{NaCl}$ concentrations also showed EPS production ability. EPS production has been reported before as a crucial factor for abiotic stress tolerance including salinity and temperature, due to their ability to bind to cations, including $\mathrm{Na}^{+}$(Geddie \& Sutherland, 1995). In some cases, EPS production even increased under extreme conditions (Sandhya \& Ali, 2015).

\section{Bacterial functional diversity and most promising isolates}

Figure 2 shows that none of the rhizospheric isolates were able to present all functional characteristics tested. However, some isolates shared several characteristics to promote in vitro plant growth.

High temperatures, high salt concentrations and reduced water activity resulted in a deleterious effect on the evaluated bacterial community. However, isolates with physiological and metabolic capacity to tolerate such conditions were selected. Among the characteristics that can confer bacteria tolerance to high temperatures, high saline concentrations, and water deficit; RNA and DNA alteration, proteins composition (Nakashima et al., 2003), production of exopolysaccharides, biofilm and organic osmolytes can be mentioned (Qurashi \& Sabri, 2011).

Data regarding the traits for plant growth promotion and in vitro abiotic stress tolerance were cross-checked, resulting in the selection of 5 isolates (Table 3 ) that were molecularly characterized and tested in vivo for water deficit tolerance.

\section{S rRNA sequencing}

Based on the 16S rRNA gene sequence identity on EzTazon Server (Yoon et al., 2017), all isolates belong to the 
Table 2. Number of isolates, plant growth promotion (PGP) and abiotic tolerance traits of bacteria isolates from three cacti rhizospheric soils in two sampling locations at 'Raso da Catarina' Ecological Station.

\begin{tabular}{|c|c|c|c|c|c|c|}
\hline \multirow{2}{*}{ Source } & \multicolumn{2}{|c|}{ Tacinga werneri } & \multicolumn{2}{|c|}{ Melocactus zehntneri } & \multicolumn{2}{|c|}{ Pilosocereus catingicola } \\
\hline & Site 1 & Site 2 & Site 1 & Site 2 & Site 1 & Site 2 \\
\hline Number of isolates & 17 & 17 & 8 & 20 & 14 & 13 \\
\hline \multicolumn{7}{|l|}{ PGP traits } \\
\hline Phosphate solubilization & 0 & 0 & 3 & 1 & 0 & 1 \\
\hline Siderophores production & 3 & 6 & 3 & 1 & 6 & 5 \\
\hline Indolic compounds production & 11 & 12 & 5 & 13 & 9 & 5 \\
\hline Biological nitrogen fixation & 8 & 5 & 1 & 10 & 8 & 1 \\
\hline EPS production & 3 & 17 & 8 & 11 & 6 & 8 \\
\hline \multicolumn{7}{|l|}{ Abiotic tolerance traits } \\
\hline $2 \% \mathrm{NaCl}$ & 4 & 14 & 7 & 17 & 10 & 10 \\
\hline $4 \% \mathrm{NaCl}$ & 4 & 11 & 5 & 13 & 5 & 9 \\
\hline $6 \% \mathrm{NaCl}$ & 2 & 10 & 4 & 8 & 3 & 8 \\
\hline $8 \% \mathrm{NaCl}$ & 1 & 9 & 3 & 7 & 2 & 6 \\
\hline $10 \% \mathrm{NaCl}$ & 0 & 2 & 0 & 6 & 0 & 3 \\
\hline $0.957 \mathrm{Aw}$ & 10 & 5 & 7 & 15 & 12 & 8 \\
\hline $0.919 \mathrm{Aw}$ & 6 & 4 & 6 & 9 & 5 & 3 \\
\hline $0.897 \mathrm{Aw}$ & 5 & 3 & 5 & 6 & 2 & 0 \\
\hline $0.807 \mathrm{Aw}$ & 2 & 1 & 3 & 5 & 2 & 0 \\
\hline $37^{\circ} \mathrm{C}$ & 16 & 15 & 6 & 19 & 14 & 12 \\
\hline $42^{\circ} \mathrm{C}$ & 16 & 14 & 6 & 17 & 14 & 12 \\
\hline $45^{\circ} \mathrm{C}$ & 14 & 14 & 4 & 13 & 10 & 12 \\
\hline $49^{\circ} \mathrm{C}$ & 0 & 3 & 0 & 3 & 2 & 2 \\
\hline
\end{tabular}
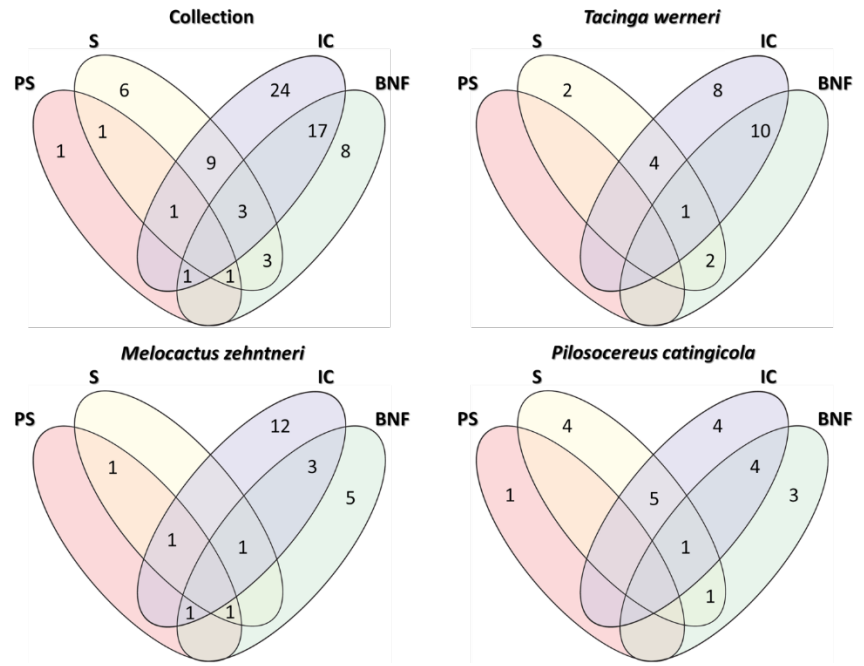

Figure 2. Venn diagram showing the occurrence and number of cacti rhizosphere isolates that displayed one or more of the plant growth-promoting traits. PS: Phosphate solubilization, S: Siderophores production, IC: Indolic compounds production and BFN: Biological nitrogen fixation. Collection: results combined from the three cacti species. genus Bacillus. Phylogenetic analysis split the isolates into two branches (Figure 3). Melocactus zehntneri isolates (CF3.1, CF6.1, CF8.2 and CF12.2) clustered in the Bacillus cereus group together with Bacillus wiedmannii, Bacillus thuringiensis and Bacillus toyonensis, whereas the Pilosocereus catingicola isolate (P12.2) clustered with Bacillus subtilis group next to Bacillus tequilensis, Bacillus axarquiensis and Bacillus mojavensis. According to the $16 \mathrm{~S}$ rRNA gene sequence, CF3.1 and CF6.1 isolates exhibited $100 \%$ and $99,9 \%$ similarity with B. toyonensis. Both CF8.2 and CF12.2 isolates showed $100 \%$ and $99,5 \%$ of similarity with $B$. wiedmannii. Lastly, P12.2 has $16 \mathrm{~S}$ rRNA $98,8 \%$ similarity with $B$. tequilensis. The clustering of the isolates was associated with the plant species where $\mathrm{CF}$ isolates came from Melocactus zehntneri and the $\mathrm{P}$ isolate from Pilosocereus catingicola (Figure 3).

$16 \mathrm{~S}$ rRNA analyzes in this study showed that all isolates recovered from the cacti rhizosphere were members of the genus Bacillus. It is well known that species belonging to the Bacillus genus are endospore-forming bacteria, and it seems to be directly related to their ability to inhabit soils with reduced water availability. Recent studies showed the

Table 3. Plant growth-promoting and abiotic tolerance characteristics of selected isolates used for an in vitro an in vivo experiments in maize plants

\begin{tabular}{|c|c|c|c|c|c|c|c|c|c|c|c|c|}
\hline \multirow{3}{*}{ Isolate } & \multirow{2}{*}{\multicolumn{5}{|c|}{ Plant growth promotion trait }} & \multicolumn{7}{|c|}{ Abiotic stress tolerance } \\
\hline & & & & & & \multicolumn{3}{|c|}{$[\mathrm{NaCl}](\%)$} & \multicolumn{3}{|c|}{ Temperature $\left({ }^{\circ} \mathrm{C}\right)$} & \multirow{2}{*}{$\begin{array}{c}0.807 \\
\text { Aw }\end{array}$} \\
\hline & $\mathrm{PS}^{\mathbf{a}}$ & $\mathbf{S}^{\mathbf{b}}$ & ICC & $B N F^{d}$ & MRCe & 6 & 8 & 10 & 42 & 45 & 49 & \\
\hline P12.2 & - & + & + & - & + & + & + & - & + & + & - & + \\
\hline CF3.1 & - & - & + & - & + & + & - & - & + & - & - & + \\
\hline CF6.1 & + & + & + & - & + & + & + & - & + & + & - & + \\
\hline CF8.2 & - & - & + & - & + & + & + & + & + & + & + & + \\
\hline CF12.2 & - & - & + & + & + & + & + & + & + & + & - & + \\
\hline
\end{tabular}

aPS: Phosphate solubilization; ${ }^{\mathrm{b} S}$ : Siderophores production; $\mathrm{C} C$ : Indolic compounds production; ${ }^{\mathrm{d} B F N}$ : Biological nitrogen fixation; ${ }^{\mathrm{e} M R C:}$ Maize root colonization (in vitro). 


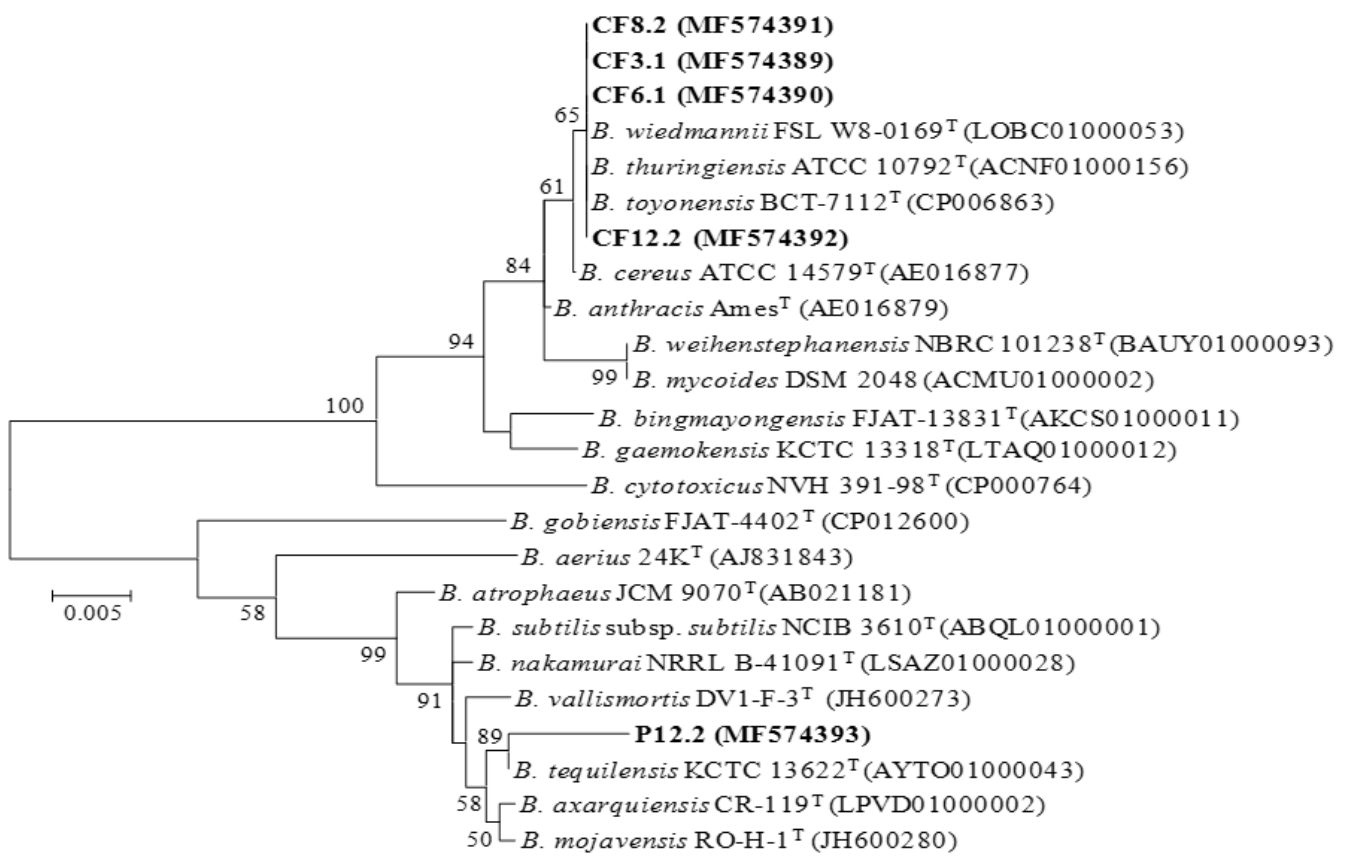

Figure 3. Neighbor-Joining phylogenetic tree based on $16 \mathrm{~S}$ rRNA partial sequences ( $952 \mathrm{bp}$ ) from the cacti rhizosphere isolates. Numbers at branch points indicate bootstrap percentages based on 1000 replicates. Only values greater than $50 \%$ are shown.

prevalence of this bacterial group in association with native Cactaceae in Brazilian and Mexican soils (Kavamura et al., 2013b; Fonseca-García et al., 2016). According to Ghosh et al. (2015), endospores present minimal metabolism and exhibit a high degree of resistance to various physical factors including high temperatures and extreme desiccation, conditions that can be found in the Caatinga biome. Thus, spore production may explain the survival of these microbial communities associated to the plants studied, since about $50 \%$ of the isolates produced endospores (data not shown).

Plant growth promotion and water stress amelioration in maize plants

The most promising isolates in the tolerance test for in vitro drought conditions were Bacillus sp. CF12.2, Bacillus sp. CF6.1, Bacillus sp. CF3.1, Bacillus sp. CF8.2 and Bacillus sp. P12.2, which were inoculated in maize seeds for water deficit tolerance test. In $80 \%$ of the soil water-holding capacity (WC), Bacillus sp. CF12.2, Bacillus sp. CF3.1 and Bacillus sp. CF8.2 were able to influence the increment in root length ( $p$ $<0,0105)$, number of leaves $(p<0,001)$, root $(p<0,001)$ and shoot dry weight $(p<0,001)$ (Figure 4). However, when plants were under water deficit ( $30 \% \mathrm{WC}$ ), only the shoot dry weight $(p<0,001)$ parameter showed a significant increase when inoculated with Bacillus sp. CF6.1, Bacillus sp. CF3.1, Bacillus sp. CF8.2 and Bacillus sp. P12.2.

The in vitro growth promotion characteristics showed by Bacillus sp. isolates from cacti may have influenced the observed results of the in vivo evaluated parameters. The specific mechanisms for these increases were not determined. The length increases in inoculated roots, especially with Bacillus sp. CF6 under the recommended irrigation suggest that these isolates could alter the plant physiology and morphology. In comparison with root biomass, root length highly affects the plant performance to scavenge water and nutrients from the soil (Hodge, 2005). This trait indicates that plants with a higher root length are probably more efficient to grow and survive in water and nutrient-limited environments. These alterations are mainly induced by auxins, such as indole acetic acid (Fukaki \& Tasaka, 2009), present in the tested isolates, in addition to volatile compounds production (Delaplace et al., 2015). The inoculated plants showed higher potential for water and nutrient uptake, which can be carried out through the solubilization of inorganic phosphate, siderophores production and/or fixation of atmospheric nitrogen, characteristics present in the evaluated isolates.

The EPS production found in $59 \%$ of the isolates recovered from the cacti rhizosphere and present in all isolates used for plant growth promotion tests and tolerance to water deficit may be related to the observed increments. Bacterial EPS can influence plant growth through aggregation and soil adhesion to the root system, promoting better nutrition with higher nutrients availability (Costa et al., 2018). Additionally, these bacteria are able to form a biofilm, which increases the root system retention capacity and water availability, creating a hydrated microenvironment (Chang et al., 2007; Timmusk \& Nevo, 2011); giving to plants the capacity to develop, even under reduced water availability. In addition to these aspects, EPS are structures responsible for allowing bacterial colonization to the plant root system, being one of the first characteristics required to assure microorganisms and plant interaction, leading to a more stable and efficient interaction (Bianciotto et al., 2001). This characteristic was present in all isolates tested.

Crops of agricultural importance such as potato, maize, and wheat when inoculated with rhizobacteria with growth- 

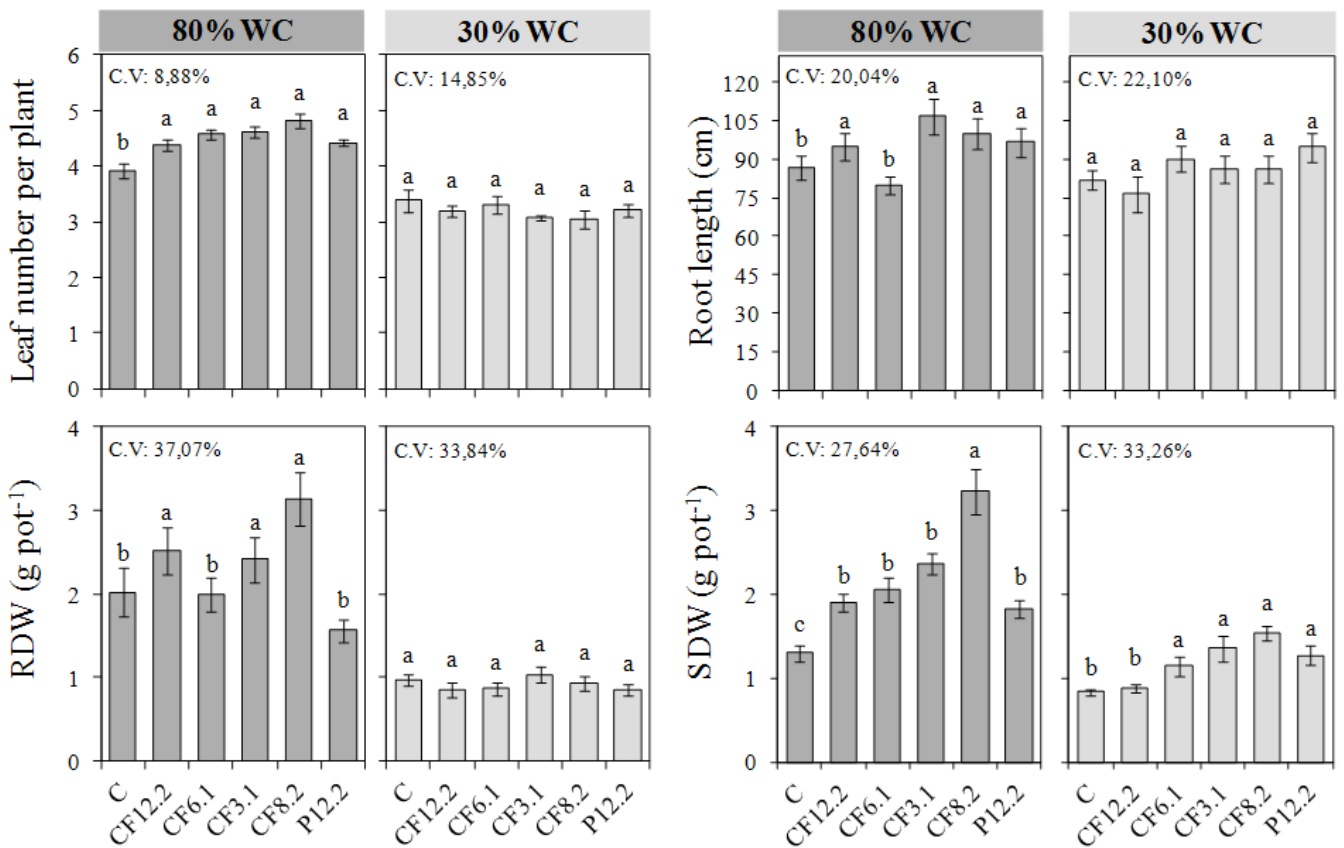

Figure 4. Growth-promoting effects of Bacillus isolates and a non-inoculated control (C) on leaf number per pot, root length, root (RDW) and shoot (SDW) dry weight in maize plants in a non-sterile soil under $80 \%$ and $30 \%$ water-holding capacity (WC) of the soil. Error bars indicate standard deviation based on 13 replicates of plants grown. Different letters indicate difference $(p<0.05)$ between the treatments in the same water-holding scenario.

promoting characteristics showed better agronomic performance when compared with treatments without inoculation (Jarak et al., 2012; Dawwam et al., 2013; Majeed et al., 2015). In our study, all isolates tested promoted an increase in the shoot dry weight of maize plants when compared to those of the non-inoculated control under non-limiting water condition (Figure 4). Similar results were observed when bacteria tolerant to drought conditions reduced the effects caused by abiotic salinity stress in common bean inoculated with Azospirillum brasilense (Dardanelli et at., 2008), water deficit in maize supplied with selected Pantoea sp. and Bacillus sp. (Kavamura et al., 2013a), severe water deficit in sorghum inoculated with Bacillus sp. (Santana et al., 2020) and tolerance to high temperatures in sorghum with Pseudomonas sp. KM-P6 added (Ali et al., 2009). Four (CF3.1, CF6.1, CF8.2, and P12.2) of the five isolates tested in this study helped maize plants to grow under water limiting conditions (Figure 4). Bacillus helping maize plants to develop under water limiting condition was reported before by Kavamura et al. (2013a), when the authors tested Bacillus isolated from cacti rhizosphere, similar to our study. The observed results associated to the finds of Kavamura et al. (2013a) could give us an insight that the cacti rhizosphere is a favorable environment for finding bacteria with potential to help plants under drought conditions, mainly those of agricultural interest.

This study showed that rhizobacteria associated with cacti harbor several mechanisms to promote plant growth and tolerance to abiotic stress. These bacteria may play an important role in the development and survival of native host plants and may contribute to the development of a microbial biostimulants for crops in the semi-arid regions. Our research provides insights for the development of deeper studies focus on the functional diversity of microorganisms associated with the Caatinga native vegetation, with potential application in several sectors, improving the sustainable agriculture in arid and semi-arid regions of Brazil.

\section{Conclusions}

Melocactus zehntneri showed larger higher culturable rhizospheric bacterial population than Tacinga werneri and Pilosocereus catingicola.

All evaluated isolates were positive for at least one plant growth promotion trait, being indolic compounds production the most frequent in our collection.

Cacti species examined were colonized by PGPR bacteria, being able to promote maize growth even under drought stress.

All strains in our study belonged to the Bacillus genus. Strains CF12.2, CF3.1 and CF8.2 promoted maize growth under standard irrigation conditions.

Under water deficit, isolates CF6.1, CF3.1, CF8.2 and P12.2 increased the shoot dry weight.

It was identified bacteria for further validation and application as biostimulants in crops cultivated in drylands.

\section{Acknowledgements}

AFJS thanks to National Council for Scientific and Technological development (CNPq) (Process 409309/2016-8) for the financial support. JL thanks the Foundation for Research Support of the State of Alagoas (FAPEAL) for the support by 
the Regional Scientific and Technological development in association with CNPq (Process 301412/2016-2). PIFJ thanks to CNPq to the research productivity fellowship (311218/20172) and Brazilian Agricultural Research Corporation (Process 23.13.00.003.00.00) for financial support.

\section{Conflict of Interest Statement}

The authors declare no conflict of interest.

\section{Compliance with Ethical Standards}

This project was conducted with the authorization of The Chico Mendes Institute for Biodiversity Conservation (ICMBio), with the register number 3670430 .

\section{Literature Cited}

Aguirre-Garrido, J.F.; Montiel-Lugo, D.; Hernández-Rodríguez, C.; Torres-Cortes, G.; Millán, V.; Toro, N.; Martínez-Abarca, F.; Ramírez-Saad, H.C. Bacterial community structure in the rhizosphere of three cactus species from semi-arid highlands in central Mexico. Antonie van Leeuwenhoek, v.101, p.891-904, 2012. https://doi.org/10.1007/s10482-012-9705-3.

Albdaiwi, R.N.; Khyami-Horani, H.; Ayad, J.Y.; Alananbeh, K.M.; AlSayaydeh, R. Isolation and characterization of halotolerant plant growth promoting rhizobacteria from durum wheat (Triticum turgidum subsp. durum) cultivated in saline areas of the Dead Sea region. Frontiers in Microbiology, v. 10, article 1639, 2019. https://doi.org/10.3389/fmicb.2019.01639.

Ali, S.Z.; Sandhya, V.; Grover, M.; Kishore, N.; Rao, L.V.; Venkateswarlu, B. Pseudomonas sp. Strain AKM-P6 enhances tolerance of sorghum seedlings to elevated temperatures. Biology Fertility Soils, v.49, p.45-55, 2009. https://doi.org/10.1007/s00374-009-0404-9.

Ashraf, A.; Bano, A.; Ali, S.A. Characterization of plant growth promoting rhizobacteria from rhizospheric soil of heat stressed and unstressed wheat and their use as bio -inoculant. Plant Biology, v.21, n.4, p. 762-769, 2019. https://doi.org/10.1111/plb.12972.

Bashan, Y.; Rojas, A.; Puente, M.E. Improved establishment and development of three cactus species inoculated with Azospirillum brasilense transplanted into disturbed urban desert soil. Canadian Journal of Microbiology, v. 45, n.6 p. 441-451, 1999. https://doi.org/10.1139/w99-043.

Berg, G.; Smalla, K. Plant species and soil cooperatively shape the structure and function of microbial communities in the rhizosphere. FEMS Microbiology Ecology, v.68, n.1, p.1-13, 2009. https://doi.org/10.1111/j.1574-6941.2009.00654.x.

BFG - The Brazilian flora group. Growing knowledge: an overview of seed plant diversity in Brazil. Rodriguésia, v.66, n.4, p. 1085-1113, 2015. https://doi.org/10.1590/2175-7860201566411.

Bianciotto, V.; Andreotti, S.; Balestrini, R.; Bonfante, P.; Perotto, S. Mucoid mutants of the biocontrol strain Pseudomonas fluorescens $\mathrm{CHAO}$ show increased ability in biofilm formation on mycorrhizal and nonmycorrhizal carrot roots. Current Opinion in Microbiology, v. 14, n.2, p. 255-260, 2001. https://doi. org/10.1094/MPMI.2001.14.2.255.
Chang, W. S.; van de Mortel, M.; Nielsen, L.; Nino de Guzman, G.; Li, X.; Halverson, L. J. Alginate production by Pseudomonas putida creates a hydrated microenvironment and contributes to biofilm architecture and stress tolerance under water limiting conditions. Journal of Bacteriology, v. 189, n.22, p. 8290-8299, 2007. https:// doi.org/10.1128/JB.00727-07.

Chaparro, J. M.; Bradri, D.V.; Vivanvo, J. M. Rhizosphere microbiome assemblage is affected by plant development. ISME Journal, v.8, p.790-803, 2014. https://doi.org/10.1038/ismej.2013.196.

Costa, O. Y.A.; Raaijmakers, J.M.; Kuramae, E.E. Microbial extracellular polymeric substances: ecological function and impact on soil aggregation. Frontiers in Microbiology, v.9, article 1636, 2018. https://doi.org/10.3389/fmicb.2018.01636.

Dalal, J.; Kulkarni, N. Antagonistic and plant growth promoting potentials of indigenous endophytic bacteria of soybean (Glycine max (L) Merril). Current Research in Microbiology and Biotechnology, v.1, n.2, p.62-69, 2013. http://crmb. aizeonpublishers.net/content/2013/2/crmb62-69.pdf. 19 Jan. 2020.

Dardanelli, M. S.; Fernández de Cordoba, F.J.; Espuny, M.R.; Rodríguez Carvajal, M.A.; Soria Diaz, M.E.; Gil Serrano, A.M.; Okon, Y.; Megías, M. Effect of Azospirillum brasilense co-inoculated with Rhizobium on Phaseolus vulgaris flavonoids and nod factor production under salt stress. Soil Biology and Biochemistry, v. 40, n.11, p.2713-2721, 2008. https://doi.org/10.1016/j. soilbio.2008.06.016

Dawwam, G.E.; Elbeltagy, A.; Emara, H.M.; Abbas, I.H.; Hassan, M.M. Beneficial effect of plant growth promoting bacteria isolated from the roots of potato plant. Annals of Agriculture Science, v.58, n.2, p.195-201, 2013. https://doi.org/10.1016/j.aoas.2013.07.007.

Delaplace, P.; Delory, B.M.; Baudson, C.; Cazenave, M.M.S.; Spaepen, S.; Varin, S.; Brostaux, Y.; Jardin, P. du. Influence of rhizobacterial volatiles on the root system architecture and the production and allocation of biomass in the model grass Brachypodium distachyon (L.) P. Beauv. BMC Plant Biology, v.15, article 65, 2015. https://doi.org/10.1186/s12870-015-0585-3.

Ferreira, D.F. Sisvar: a computer statistic alanalysis system. Ciência e Agrotecnologia, v.35, n.6, p.1039-1042, 2011. https://doi. org/10.1590/S1413-70542011000600001.

Fonseca-García, C.; Coleman-Derr, D.; Garrido, E.; Visel, A.; Tringe, S.G.; Partida-Martínez, L.P. The cacti microbiome: interplay between habitat-filtering and host-specificity. Frontiers in Microbiology, v.7, article 150, 2016. https://doi.org/10.3389/ fmicb.2016.00150.

Fukaki, H.; Tasaka, M. Hormone interactions during lateral root formation. Plant Molecular Biology, v.69, article 437, 2009. https://doi.org/10.1007/s11103-008-9417-2.

Geddie, J.L.; Surtherland, I.W. Uptake of metals by bacterial polysaccharides. Journal of Applied Bacteriology, vol.74, n.4, p.467-472, 1993. https://doi.org/10.1111/j.1365-2672.1993. tb05155.x.

Ghosh, S.; Korza, G.; Maciejewskki, M.; Setlow, P. Analysis of metabolism in dormant spores of Bacillus species by 31P nuclear magnetic resonance analysis of low-molecular-weight compounds. Journal of Bacteriology, v. 197, n.5, p. 992-1001, 2015. https://doi.org/10.1128/JB.02520-14. 
Giulietti, A.M.; Neta, A.L.B.; Castro, A.A.J.F.; Gamara-Rojas, C.F.L.; Sampaio, E.V.S.B.; Virgínio, J.F.; Queiroz, L.P.; Figueiredo, M.A.; Rodal, M.J.N.; Barbosa, M.R.V.; Harkey, R.M. Diagnóstico da vegetação nativa do Bioma Caatinga. In: Silva, J. M. C. da; Tabarelli, M.; Fonseca, M. T. da; Lins, L. V. (Orgs.). Biodiversidade da caatinga: áreas e ações prioritárias para a conservação. Brasília: Ministério do Meio Ambiente: Universidade Federal de Pernambuco, 2003. p. 48-78. http://ainfo.cnptia.embrapa.br/digital/bitstream/ item/18267/1/Biodiversidade_Caatinga_parte2.pdf. 14 Jan. 2020.

Gordon, S.A.; Weber, R.P. Colorimetric estimation of indolacetic acid. Plant Physiology, v.26, n.1, p.192-195, 1951. https://doi. org/10.1104/pp.26.1.192.

Guerrero, P.C.; Majure, L.C.; Cornejo-Romero, A.; HernándezHernández, T. Phylogenetic relationships and evolutionary trends in the cactus family. Journal of Heredity, v.110, n.1, p. 4-21, 2019. https://doi.org/10.1093/jhered/esy064.

Guimarães, D.P.; Costa, F.; Rodrigues, M.J.; Maugeri, F. Optimization of dextran synthesis and acidic hydrolysis by surface response analysis. Brazilian Journal of Chemical Engineering, v.16, n.2, p.129139, 1999. https://doi.org/10.1590/S0104-66321999000200004.

Hallsworth, J.E.; Nomura, Y.; Iwahara, M. Ethanol-induced water stress and fungal growth. Journal of Bioscience and Bioengineering, v.86, n.5, p. 451-456, 1998. https://doi.org/10.1016/S0922$338 \times(98) 80150-5$.

Hodge, A. Nitrogen in soil /Plant Uptake. Encyclopedia of Soils in the Environment. Reference Module in Earth Systems and Environmental Sciences, p.39-46, 2005. https://doi.org/10.1016/ B0-12-348530-4/00159-4.

Jarak, M.; Mrkovacki, N.; Bjelic, D.; Josic, D.; Hajnal-Jafari, T.; Stamenov, D. Effects of plant growth promoting rhizobacteria on maize in greenhouse and field trial. African Journal of Microbiology Research, v.6, n.27, p.5683-5690, 2012. https://doi. org/10.5897/AJMR12.759.

Kavamura, V.N.; Santos, S.N.; Parma, M.M.; Ávila, L.A.; Visconti, A.; Zucchi, T.D.; Taketani, R.G.; Andreote, F.D.; Melo, I.S. Screening of Brazilian cacti rhizobacteria for plant growth promotion under drought. Microbiological Research, v.168, n.4, p.183-191, $2013 a$. https://doi.org/10.1016/j.micres.2012.12.002.

Kavamura, V.N.; Taketani, R.G.; Lançoni, M.D.; Andreote, F.D.; Mendes, R.; Melo, I.S. Water regime influences bulk soil and rhizosphere of Cereus jamacaru bacterial communities in the Brazilian Caatinga Biome. PLoS ONE, v.8, n.9, e73606, 2013b. https://doi.org/10.1371/journal.pone.0073606.

Kim, S.; Lowman, S.; Hou, G.; Nowak, J.; Flinn, B.; Mei, C. Growth promotion and colonization of switchgrass (Panicum virgatum) cv. Alamo by bacterial endophyte Burkholderia phytofirmans strain PsJN. Biotechnology for Biofuels, v.5, article 37, 2012. https://doi.org/10.1186/1754-6834-5-37.

Louden, B.C.; Haarmann, D.; Lynne, A.M. Use of blue agar CAS assay for siderophore detection. Journal of Microbiology \& Biology Education, v.12, n.1, p.51-53, 2011. https://doi.org/10.1128/jmbe.v12i1.249.

Lucena, C.M. de; Lucena, R.F.P. de; Costa, G.M.; Carvalho, T.K.N.; Costa, G.G.S.; Alves, R.R.N.; Nunes, E.N. Use and knowledge of Cactaceae in Northeastern Brazil. Journal of Ethnobiology and Ethnomedicine, v.9, article 62, 2013. http://doi. org/10.1186/1746-4269-9-62.
Maharana, P.K. Isolation and characterization of IAA producing plant growth promoting rhizobacteria (PGPR) from rhizospheric soil of ornamental (Marigold) plant. International Journal of Life Science, v.7, n.2, p.333-336, 2019. http://oaji.net/ articles/2019/736-1561598952.pdf. 21 Jan. 2020.

Majeed, A.; Abbasi, M.K.; Hameed, S.; Imran, A.; Rahim, N. Isolation and characterization of plant growth-promoting rhizobacteria from wheat rhizosphere and their effect on plant growth promotion. Frontiers in Microbiology, v.6, article 198, p.1-10, 2015. https://doi.org/10.3389/fmicb.2015.00198.

Micallef, A.S.; Shiaris, M.P.; Colón-Carmona, A. Influence of Arabidopsis thaliana acessions on rhizobacterial communities and natural variation in root exudates. Journal of Experimental Botany, v.60, n.6, p.1729-1742, 2009. https://doi.org/10.1093/jxb/erp053.

Mutumba, F.A.; Zagal, E.; Gerding, M.; Castillo-Rosales, D.; Paulino, L.; Schoebitz, M. Plant growth promoting rhizobacteria for improved water stress tolerance in wheat genotypes. Journal of Soil Science and Plant Nutrition, v.18, n.4, p.1080-1096, 2018. https://doi.org/10.4067/S0718-95162018005003003.

Nakashima, H.F.S.; Nishikawa, K. Compositional changes in RNA, DNA and proteins bacterial adaptation to higher and lower temperatures. Journal of Biochemistry, v.133, n.4, p.507-513, 2003. https://doi.org/10.1093/jb/mvg067.

Ogbo, F.; Okonkwo, J. Some Characteristics of a plant growth promoting Enterobacter sp. Isolated from the roots of maize. Advances in Microbiology, v.2, n.3, p.368-374, 2012. https://doi. org/10.4236/aim.2012.23046.

Pahari, A.; Pradhan, A.; Nayak, S.K.; Mishra, B.B. Bacterial siderophore as a plant growth promoter. In: Patra J.; Vishnuprasad, C.; Das, G. (Eds.). Microbial biotechnology. Singapore: Springer, 2017. p.163-180. https://doi.org/10.1007/978-981-10-6847-8_7.

Paulo, E.M.; Vasconcelos, M.P.; Oliveira, I.S.; Affe, H.M.J.; Nascimento, R.; Melo, I.S.; Roque, M.R.A.; Assis, A.S. An alternative method for screening lactic acid bacteria for the production of exopolysaccharides with rapid confirmation. Ciência e Tecnologia de Alimentos, v.32, n.4, p.710-714, 2012. https://doi. org/10.1590/S0101-20612012005000094.

Puente, M.E.; Li, C.Y.; Bashan, Y. Endophytic bacteria in cacti seeds can improve the development of cactus seedlings. Environmental and Experimental Botany, n.3, v. 66, p. 402-408, 2009. https:// doi.org/10.1016/j.envexpbot.2009.04.007.

Queiroz, B.P.V.; Aguilar-Vildoso, C.I.; Melo, I.S. Visualização in vitro da colonização de raízes por rizobactérias. Summa Phytopathologica, v.32, n.1, p.95-97, 2006. https://doi.org/10.1590/S010054052006000100017.

Qurashi, A.W.; Sabri, A.N. Osmoadaptation and plant growth promotion by salt tolerant bacteria under salt stress. African Journal of Microbiology Research, v.5, n.21, p.3546-3554, 2011. https://doi.org/10.5897/AJMR11.736.

Ryan, R.P.; Monchy, S.; Cardinale, M.; Taghavi, S.; Crossman, L.; Avison, M.B.; Berg, G.; Van der Lelie, D.; Dow, J.M. The versatility and adaptation of bacteria from the genus Stenotrophomonas. Nature Reviews Microbiology, v.7, p.514-525, 2009. https://doi. org/10.1038/nrmicro2163.

Sandhya, V.; Ali, Sk. Z. The Production of Exopolysaccharide by Pseudomonas putida GAPP45 under Various Abiotic Stress Conditions and Its Role in Soil Aggregation. Microbiology, v.84, p.512-519, 2015. https://doi.org/10.1134/S0026261715040153. 
Santana, S.R.A.; Voltolini, T.V.; Antunes, G. dos R.; da Silva, V.M.; Simões, W.L.; Morgante, C.V.; de Freitas, A.D.S.; Chaves, A.R. de M.; Aidar, S. de T.; Fernandes-Júnior, P.I. Inoculation of plant growth-promoting bacteria attenuates the negative effects of drought on sorghum. Archives of Microbiology, v.202, n.5, p.1015-1024, 2020. https://doi.org/10.1007/s00203-020-018105

Santos, A.F.J.; Martins, C.Y.S.; Santos, P.O.; Corrêa, E.B.C.; Barbosa, H.R.; Sandoval, A.P.S.; Oliveira, L.M.; Souza, J.T.; Soares, A.C.F. Diazotrophic bacteria associated with sisal (Agave sisalana Perrine ex Engelm): potential for plant growth promotion. Plant and Soil, v.385, p.37-48, 2014. https://doi.org/10.1007/s11104014-2202-x.

Silva, S.R.; Zappi, D.; Taylor, N.; Machado, M. (Orgs.). Plano de ação nacional para a conservação das Cactáceas. Brasília: ICMBio, 2011. 112p. (Série Espécies Ameaçadas, 24). https://www. icmbio.gov.br/portal/images/stories/docs-plano-de-acao/pan_ cactaceas/livro_cactaceas_web.pdf. 10 Jan. 2020.
Tamura, K.; Stecher, G.; Peterson, D.; Filipski, A.; Kumar, S. MEGA6: Molecular evolutionary genetics analysis version 6.0. Molecular Biology and Evolution, v.30, n.12, p.2725-2729, 2013. https://doi. org/10.1093/molbev/mst197.

Timmusk, S.; Nevo, E. Plant root associated biofilms: perspectives for natural product mining. In: Maheshwari, D. K. (Ed.). Bacteria in agrobiology: plant nutrient management. Berlin: Springer Verlag, 2011. p.285-300. https://doi.org/10.1007/978-3-642-21061-7_12.

Weisburg, W.G.; Barns, S.M.; Pelletier, D.A.; Lane, D.J. $16 \mathrm{~S}$ ribosomal DNA amplification for phylogenetic study. Journal of Bacteriology, v.173, n.2, p.697-703, 1991. https://doi.org/10.1128/JB.173.2.697-703.1991.

Wilson, P.W.; Knight, S.C. Experiments in bacterial physiology. 3.ed. Minneapolis: Burgess, 1952. 61p.

Yoon, S-H.; Ha, S-M.; Kwon, S.; Lim, J.; Kim, Y.; Seo, H.; Chun, J. Introducing EzBioCloud: A taxonomically united database of 16S rRNA and whole genome assemblies. International Journal of Systematic and Evolutionary Microbiology, v. 67, n.5, p.16131617, 2017. https://doi.org/10.1099/ijsem.0.001755. 